\title{
Who's Teaching the Teachers? Evidence from the National Survey of Postsecondary Faculty and the Survey of Earned Doctorates
}

\author{
LISA WOLF-WENDEL, BRUCE D. BAKER, SUSAN TWOMBLY, \\ NONA TOLLEFSON, and MARC MAHLIOS \\ University of Kansas
}

In light of a documented shortage of candidates for teacher education faculty positions, this study explores the academic labor market for teacher education faculty utilizing data from the National Survey on Postsecondary Faculty and the Survey of Earned Doctorates. The study sheds light on the factors that predict who becomes a faculty member in teacher education.

Schools of education are experiencing an apparent shortage of qualified individuals who are willing to assume faculty positions in teacher education, especially at research universities. A shortage of qualified applicants for faculty positions in research universities is of concern for at least two reasons: research universities are the places that are expected to produce the new knowledge on which a vibrant profession depends. In addition, research universities have as their mission to produce future leaders of the profession, including the professoriate. If research universities are unable to hire faculty in teacher education to maintain these goals, one has to wonder what the future portends for the field of teacher education. Little research has been conducted that examines this potential shortfall of teacher education faculty and the reasons behind it. The present study uses two national data sets to answer the following research questions: What are the factors that predict who is most likely to become a faculty member among those receiving doctorates in teacher education? And what are the factors that predict whether those who seek faculty positions will work at a research university?

Studies report that unfilled vacancies for teacher education faculty positions are substantial, ranging from 25 percent in 1998-99 (Castle and Arends 2003) to 36 percent in 2001 (Twombly et al. 2003). Studies of special education (Smith et al. 2001) and mathematics education (Reyes 2002) searches found

A merican Journal of Education 112 (February 2006)

(c) 2006 by The University of Chicago. All rights reserved.

0195-6744/2006/11202-0004\$05.00 
that for 2000-2001 30 percent of special education searches were unable to fill faculty positions with qualified candidates, while nearly half the searches in mathematics education went unfilled. Search chairs used terms like "abysmal" and "in grave trouble" to describe the state of the labor market, and they rated candidate pools as marginal to fair (Twombly et al. 2003).

Another way to look at the supply of faculty is to examine the Survey of Earned Doctorates (SED) to ascertain the size of the potential pool. Overall, the number of doctorates awarded in education declined by 3.4 percent between 1991 and 2000 (Farrell 2001), but this masks differences by subfield. Doctoral productivity in foundations, social science education, reading, and educational technology increased between 1990 and 2000, while other subfields experienced declines (e.g., general curriculum and instruction; Twombly et al. 2003).

More troubling, however, is that in 2000, only 41 percent of those earning doctorates in teacher education fields reported being interested in becoming faculty members (Twombly et al. 2003). This percentage varies slightly by subfield. Within fields like foundations and mathematics education, 55 percent of the doctoral recipients in 2000 wished to become faculty, while, within fields like foreign language and early childhood education, only 32 percent expressed a similar intent. Additionally, one-third to one-half of those who planned on being faculty members upon earning their doctorates already held faculty positions while in graduate school. These findings do not bode well for the supply of qualified teacher education faculty.

Several factors may have contributed to declining pools of candidates for teacher education faculty posts over the past decade. A booming economy leading to expanded career options for doctoral-level educators may be one factor (Smith et al. 2001). Ever-changing state licensure or certification standards coupled with rising expectations for university promotion and tenure also pose a dilemma for hiring teacher educators. For example, attempting to hire individuals with doctorates and significant public school teaching experience to staff increasingly complex teacher education programs may pose particular problems in certain fields, especially in research universities (Labaree 2003). The fact that doctoral recipients in teacher education fields tend to be

LISA WOLF-WENDEL is an associate professor of higher education at the University of Kansas. BRUCE D. BAKER is an associate professor of educational administration at the University of Kansas. SUSAN TWOMBLY is a professor of higher education at the University of Kansas. NONA TOLLEFSON was a professor of psychology research in education at the University of Kansas. She passed away June 26, 2004. MARC MAHLIOS is a professor of curriculum and instruction at the University of Kansas. 
female and older may also restrict mobility and interest in pursuing faculty positions.

Teachers for $\mathrm{K}-12$ schools can be trained in a variety of educational institutions; however, those who train the teacher educators and who develop the knowledge base of the profession cannot be. This special role makes the situation for faculty hiring in research universities particularly critical. Schools of education in research universities may be forced to rethink what they look for in faculty and how they attract individuals to the professoriate. If research universities are going to continue to prepare the future teacher educators and to develop the knowledge base, we must understand the academic labor market in teacher education. Such attention to the labor market and employment conditions for teacher educators is long overdue.

\section{Conceptual Framework}

The study is framed by two bodies of literature: the descriptive research on teacher education faculty members and characteristics of recipients of education doctorates and the literature on the more general academic labor market. Descriptive studies of teacher education faculty and doctoral recipients provide the basis for choosing the demographic variables included in our analyses. The majority of teacher education faculty members have historically been and continue to be white and male (between 58 percent and 70 percent, depending on area of specialization; Ducharme and Agne 1982, 1989; Tierney 2001; Zimpher and Sherrill 1996). The majority of doctoral recipients in education, however, are women (Farrell 2001). Further, education doctoral recipients are more likely to be persons of color (20 percent) than is the case among teacher education faculty (10 percent; Tierney 2001). These findings suggest the importance of utilizing both race and gender as variables in our analyses.

Education faculty are more likely to have attended graduate school part time, have had prior work experience in $\mathrm{K}-12$ settings, have incurred debt while in graduate school, and be older than doctoral recipients in other fields (Ducharme and Agne 1989; Farrell 2001; Smith et al. 2001; Turner 2001). Furthermore, an increasing proportion of doctoral degrees in education are being awarded by nonelite public and private universities (Turner 2001). Specifically, Turner notes that in 1966, elite public and private research universities granted 70 percent of doctoral degrees in education, while in 1995 this percentage declined to approximately 50 percent. These factors may militate against pursuing faculty careers. Based on these findings, we include variables related to undergraduate institution, graduate institution, prior work experience, graduate student status (part time vs. full time), and amount of debt 
incurred in our analyses. We are unable to measure other characteristics of teacher educators, for example, whether they come from lower-middle- to middle-class backgrounds or were first-generation college students (Ducharme and Agne 1989), that might affect career aspirations.

The present study is also informed by the general academic labor market literature that is dominated by the idea that status and prestige are key predictors of who obtains faculty jobs and in which types of colleges and universities (Caplow and McGee 1958). Success in attaining faculty positions has largely been attributed to ascriptive characteristics such as the status of graduate mentors or the status of degree-granting institutions (Burke 1988; Finnegan 1993; Lewis 1975). The job competition model extends this idea by proposing that colleges, universities, and departments, and consequently faculty positions, are aligned in a status hierarchy. In this view, the highest-quality candidates (often determined by ascriptive characteristics) are matched with the highestquality institutions or departments, leaving the rest to be sorted among lesserquality institutions (Youn 1988). Based on this literature, one would expect research universities to fill faculty positions more easily and with higher-quality candidates than comprehensive or small nonselective liberal arts colleges. However, because of the characteristics of individuals who get doctorates in education (i.e., older, part time, and perhaps place bound) and the prominence of less selective colleges and universities in granting doctorates, these traditional academic labor models may not hold. Nonetheless, this literature directs us to attend to institutional prestige and selectivity at the undergraduate, graduate, and hiring institution levels to determine their influence on who pursues teacher education faculty positions.

\section{Method}

\section{Data}

We used two national data sets to answer our research questions. First, we characterize the present faculty in teacher education using the 1993 and 1999 administrations of the National Survey of Postsecondary Faculty (NSOPF). The NSOPF is a cross-sectional survey administered approximately every five years by the National Center for Education Statistics (2002). It covers over 20,000 faculty overall, across fields, and includes part-time and full-time fouryear and two-year college faculty. For our analyses, we focus on full-time tenured or tenure track faculty whose primary field of teaching was directly related to preservice teacher education. ${ }^{1}$ We also only looked at faculty at four-year institutions. These restrictions limited our sample to approximately 700 faculty in 1993 and 500 in 1999. Specifically, we use NSOPF data to 
identify differences between teacher education faculty working in research universities and teacher education faculty working in other four-year institutions.

Our second source of data was the SED, for which we obtained universe data for all doctorates received in education in the United States from 1990 to 2000. The SED is produced by the National Opinion Research Center and has a response rate exceeding 99 percent. We focus specifically on those individuals who received doctorates in teacher education-related fields. ${ }^{2}$ This limited our SED sample to 36,864 cases. We use the SED data to characterize the pathway to a doctorate in teacher education, including, among other things, family and lifestyle measures, predegree work status, and undergraduate institution selectivity.

\section{Statistical Models}

Our overarching goal is to conceptually connect our two disparate data sets, the NSOPF and the SED, in order to characterize the pipeline from undergraduate preparation to full-time teacher education faculty positions in research and nonresearch universities. Our first objective, using the NSOPF, is to identify the statistical predictors of who becomes a faculty member in a research university as opposed to other universities. We divide our potential predictors into three major groups: (a) preparation, $(b)$ experience, and $(c)$ personal and/or family attributes. We also include a dummy variable for geographic region, on the assumption that doctoral recipients in teacher education may not have complete mobility nationally. Regarding preparation, our primary interest lies in the types of institutions that are granting doctorates to faculty in research and nonresearch universities. We classify doctorategranting institutions by two methods. First, we use the 1994 Carnegie classifications aggregated to four categories: "research," "doctoral," "comprehensive," and "other." Second, we use an indicator of whether the doctorate-granting institution was in the U.S. Newes and World Report (hereafter, "U.S. Neres") top 50 for graduate schools of education. ${ }^{3}$ We use these alternative classifications in separate models because of the overlap between ranked institutions and research universities. ${ }^{*}$

Related research indicates a strong preference in schools of education, including those in research universities, for faculty with experience teaching in the $\mathrm{K}-12$ setting (Twombly et al. 2003). Consequently, we include an indicator of whether the faculty member had previously taught in $\mathrm{K}-12$ schools. Also at this stage, we use a relatively limited set of personal characteristics, including gender, minority status, and marital status. Marital status has been shown to 


\section{Who's Teaching the Teachers?}

affect geographic mobility, especially in dual-career couple situations (WolfWendel et al. 2003). Our general equation is expressed as:

$$
\text { Research } \mathrm{U}=f \text { (Preparation, Experience, Personal, Region). }
$$

Our second objective is to use SED data to estimate the predictors of who, among doctoral recipients in teacher education, is likely to pursue a career in academe. We expect that the type of institution at which individuals receive their doctorates will play a major role in determining whether they achieve faculty status (Youn 1988). We characterize doctorate-granting institutions in two ways. Again, we use the aggregated 1994 Carnegie classifications (merged with the SED from the Institutional Postsecondary Education Data set) for the first model and the indicator of whether the doctorate-granting institution was in the U.S. Newes top 50 for graduate schools of education for the second model.

We hypothesize that other experiences while in graduate school may significantly improve one's chances of becoming a faculty member. For example, we assume that having the opportunity to $(a)$ attend full time, $(b)$ teach at the college level, or $(c)$ have paid research fellowships and/or teaching assistantships may increase the likelihood that an individual pursues an academic career (Youn 1988). ${ }^{5}$ Unfortunately, the availability of such opportunities is highly related to the type of institution attended. That is, if individuals attend a highly ranked research university, they are much more likely to have access to assistantships and/or fellowships and much more likely to attend full time. In fact, one may choose to attend a research university with aspirations of working in academe, because such opportunities are available. That is, work experiences concurrent with doctoral studies are determined simultaneously with the selection of a doctorate-granting institution and are highly related. In this particular study, we handle this complexity by laying out a series of separate models. ${ }^{6}$

We estimate the predictors of whether a teacher education doctoral recipient pursued an academic career using either doctorate-granting institution measures (Preparation: U.S. Neres rank or Carnegie classification) or work and graduate school experience indicators (Experience: assistantship/fellowship, full-time attendance, debt incurred). At this stage of the pipeline, we use an expanded set of personal and family indicators, adding age at which the doctoral degree was received and number of dependents while pursuing the doctoral degree (Perna 2001). Our general equation is expressed as follows:

$$
\text { Faculty }=f \text { (Preparation, Experience, Personal). }
$$

Next, we estimate separately models to predict the likelihood that an individual $(a)$ had an assistantship or fellowship or (b) was already teaching full time at the postsecondary level while in graduate school. Both are work ex- 
perience factors we assume to be highly related with a continued career in academe. To illustrate our point that doctorate-granting institution type is likely a strong predictor of work experience concurrent with doctoral studies, we include institutional type indicators as independent variables. Again, we include our expanded personal variables on the assumption that lifestyle variables strongly influence one's ability to pursue a doctoral degree at a highly ranked research university. Our general equation for predictors of concurrent work experience is expressed as follows:

$$
\text { Experience }=f(\text { Institution, Personal) } \text {. }
$$

Finally, we estimate the predictors of whether an individual attends a research university or a top-ranked university for their doctorate in teacher education. Again, we assume personal and lifestyle variables to be potentially strong influences. At this stage of the pipeline, we also explore the role of undergraduate preparation - baccalaureate origins-focusing specifically on the selectivity status of the undergraduate institutions attended by doctoral recipients (Wolf-Wendel 1998). For our rating system, we use Barron's Profiles of American Colleges, where the lowest rating is "nonselective" and the highest two categories are "highly selective" and "most selective." We take this step for a number of reasons. We suspect that the selectivity of an individual's undergraduate institution will be a strong predictor of whether the individual (a) attends a highly ranked research university for his/her doctorate and/or (b) receives a fellowship or assistantship and, further, that either of these conditions increases one's chance of becoming a faculty member at a research university (Eide et al. 1998). That is, we expect there to be a preference in faculty hiring at research universities for the academic elite, from undergraduate to doctorate-granting institution. Our general equation for predictors of doctorate-granting institution may be expressed as follows:

$$
\text { Institution }=f(\text { Personal, Undergraduate) } \text {. }
$$

\section{Estimation}

In all cases, our dependent measures are dichotomous. Is the individual a faculty member in a research university or not? Did the individual pursue an academic career or not? Did the individual have an assistantship or fellowship or not? Did the individual work full time as a postsecondary instructor while in graduate school or not? Did the individual receive his/her doctorate from a research university or a highly ranked graduate school or not? Also, all analyses are done with individual-level data, where the individual is either a teacher education faculty member (using NSOPF data) or a doctoral recipient 
(using SED data). The NSOPF, like many large national data sets, used a sampling procedure that oversampled certain populations of faculty members, such that the total sample of faculty surveyed is not necessarily representative of the population of faculty. As such, sampling probability weights were applied for the logistic regression analysis. Sampling probability weights adjust for the likelihood, relative to the actual population, that a specific faculty member was surveyed. To ensure correct estimation of statistical significance, robust standard errors are applied. ${ }^{8}$ In all cases, odds ratios are reported for the relationship between each independent measure and the likelihood of a positive outcome.

\section{Findings}

\section{Descriptive Analysis}

We first present a basic descriptive portrait of current teacher education faculty using data from the NSOPF, followed by descriptive statistics from the SED on those who earn doctorates in teacher education. These descriptive portraits can assist the reader in contextualizing the statistical models that follow. Complete tables of descriptive statistics on all measures used in our analyses are found in the appendix. In describing current teacher education faculty, the following findings are worth noting: 59 percent are male, 70 percent are white, 70 percent are married, and 36 percent teach at research universities. A description of teacher education doctoral recipients between 1990 and 2000 yields the following: 40 percent are interested in pursuing a faculty career, 71 percent earned their doctorate from a research university, 15 percent attended either "highly" or "most" selective undergraduate institutions (using Barron's Profiles), 19 percent worked in $\mathrm{K}-12,21$ percent were employed as full-time college instructors, 17 percent held fellowships or assistantships while in graduate school, 58 percent incurred no debt, 70 percent went to school full time four or more years while in graduate school, 59 percent were over the age of 40 upon graduation, 76 percent are white, 65 percent are female, 61 percent are married, and 61 percent have children.

We highlight below several of the descriptive variables that in our later analyses appear to be most important for determining who becomes a teacher education faculty member. Table 1 , for example, summarizes the Carnegie classifications of doctorate-granting institutions of teacher education faculty in research and nonresearch universities. Notably, the vast majority of faculty in either type of institution received their doctorates at research universities. Among those who received their doctorates at research universities, in 1993, 27 percent were working as faculty in research universities, and, in 1999, 39 
Wolf-Wendel et al.

TABLE 1

Institution of Employment by Doctorate-Granting Institution: Carnegie Classification for Teacher Education Faculty

\begin{tabular}{|c|c|c|c|c|c|c|}
\hline \multirow{2}{*}{$\begin{array}{l}\text { DEGREE- } \\
\text { GRANTING } \\
\text { INSTITUTION }\end{array}$} & \multicolumn{3}{|c|}{1993 FACULTY POSITION } & \multicolumn{3}{|c|}{1999 FACULTY POSITION } \\
\hline & Non-RU & RU & Total & Non-RU & $\mathrm{RU}$ & Total \\
\hline Research & $\begin{array}{c}400 \\
(73)\end{array}$ & $\begin{array}{c}146 \\
(27)\end{array}$ & 546 & $\begin{array}{c}240 \\
(61)\end{array}$ & $\begin{array}{l}151 \\
(39)\end{array}$ & 391 \\
\hline Doctoral & $\begin{array}{l}109 \\
(80)\end{array}$ & $\begin{array}{c}7 \\
(20)\end{array}$ & 136 & $\begin{array}{c}61 \\
(77)\end{array}$ & $\begin{array}{c}18 \\
(23)\end{array}$ & 79 \\
\hline Comprehensive & $\begin{array}{c}10 \\
(100) \\
\end{array}$ & $\begin{array}{c}0 \\
(0) \\
\end{array}$ & 10 & $\begin{array}{r}5 \\
(83) \\
\end{array}$ & $\begin{array}{c}1 \\
(17) \\
\end{array}$ & 6 \\
\hline Total & $\begin{array}{c}519 \\
(75)\end{array}$ & $\begin{array}{c}173 \\
(25)\end{array}$ & 692 & $\begin{array}{l}306 \\
(64)\end{array}$ & $\begin{array}{l}170 \\
(36)\end{array}$ & 476 \\
\hline
\end{tabular}

NOTE.-RU $=$ research university. Numbers in parentheses are percentages.

percent were working in research universities. In contrast, among those who received their doctorates at doctoral institutions, in 1993, 20 percent were working as faculty in research universities, and, in 1999, 18 percent were working in research universities. Only a handful of teacher education faculty received their doctorates from comprehensive universities.

Table 2 summarizes the U.S. Neres ranking of doctorate-granting institutions of teacher education faculty in research and nonresearch universities. Notably, most top 50-ranked graduate schools of education reside in research universities. As such, it should come as no surprise that the pattern observed in table 2 is quite similar to that in table 1 . Among faculty who received their doctorates from top 50 universities, in 1993, 28 percent worked as faculty in research universities; the remainder worked in other institutional types. In 1999, 39 percent of the faculty who earned their doctorates from top 50 universities worked in research universities. Among those who earned their doctorates from unranked universities, 21 percent worked in research universities in 1993 and 31 percent did so in 1999. This may be a result of the high demand for teacher educators and the concomitant shortage of applicants.

Table 3 summarizes the career goals or postdoctoral employment of teacher education doctorates according to the U.S. Newes ranking of doctorate-granting institutions. Graduates of top 50 institutions pursue academic careers in higher education at a rate of 43 percent, and graduates of unranked institutions pursue such academic careers at a lower rate of 38 percent. Similarly, table 4 summarizes the career goals or postdoctoral employment of teacher education doctorates according to the Carnegie classification of their doctorategranting institutions. For those receiving doctorates from research universities, 
Who's Teaching the Teachers?

TABLE 2

Institution of Employment by Doctorate-Granting Institution: "U.S. Newes" Rank for Teacher Education Faculty

\begin{tabular}{|c|c|c|c|c|c|c|}
\hline \multirow{2}{*}{$\begin{array}{l}\text { DEGREE- } \\
\text { GRANTING } \\
\text { INSTITUTION }\end{array}$} & \multicolumn{3}{|c|}{1993 FACULTY POSITION } & \multicolumn{3}{|c|}{1999 FACULTY POSITION } \\
\hline & Non-RU & RU & Total & Non-RU & $\mathrm{RU}$ & Total \\
\hline Unranked & $\begin{array}{c}281 \\
(79)\end{array}$ & $\begin{array}{c}75 \\
(21)\end{array}$ & 356 & $\begin{array}{c}178 \\
(69)\end{array}$ & $\begin{array}{c}79 \\
(31)\end{array}$ & 257 \\
\hline U.S. Neres top 50 & $\begin{array}{c}260 \\
(72)\end{array}$ & $\begin{array}{c}101 \\
(28)\end{array}$ & 361 & $\begin{array}{c}149 \\
(61)\end{array}$ & $\begin{array}{c}96 \\
(39)\end{array}$ & 245 \\
\hline Total & $\begin{array}{c}541 \\
(75)\end{array}$ & $\begin{array}{l}176 \\
(25)\end{array}$ & 717 & $\begin{array}{c}327 \\
(65)\end{array}$ & $\begin{array}{c}175 \\
(35)\end{array}$ & 502 \\
\hline
\end{tabular}

NoTE. - RU $=$ research university. Numbers in parentheses are percentages.

43 percent indicated faculty positions at postsecondary institutions as their actual or intended postdoctoral employment. For doctoral recipients from doctoral and comprehensive institutions, the likelihood of pursuing an academic career appears to drop, with only 34 percent of doctoral recipients from doctoral universities and only 30 percent of doctoral recipients from comprehensive universities pursuing academic careers in higher education.

Factors Predicting Faculty Employment at Research Universities

We start our logistic regression analysis by examining the characteristics of current teacher education faculty, focusing on those traits that predict the

TABLE 3

Career Goal by Doctorate-Granting Institution: "U.S. Newes" Rank

\begin{tabular}{lccc}
\hline $\begin{array}{l}\text { DEGREE- } \\
\text { GRANTING } \\
\text { INSTITUTION }\end{array}$ & \multicolumn{3}{c}{ CAREER GOAL } \\
\cline { 2 - 4 } & Nonfaculty & Postsecondary Faculty & Total \\
\hline Unranked & 12,285 & 7,553 & 19,838 \\
& $(62)$ & $(38)$ & 17,032 \\
U.S. Newes top 50 & 9,775 & 7,257 & 36,870 \\
& $(57)$ & $(43)$ & \\
\cline { 2 - 4 } Total & 22,060 & 14,810 & $(40)$ \\
& $(60)$ & &
\end{tabular}

NOTE.-Numbers in parentheses are percentages. 
TABLE 4

Career Goal by Doctorate-Granting Institution: Carnegie Classification

\begin{tabular}{lccr}
\hline DEGREE- & \multicolumn{3}{c}{ CAREER GOAL } \\
\cline { 2 - 4 } GRANTING \\
\cline { 2 - 4 } INSTITUTION & Nonfaculty & Postsecondary Faculty & Total \\
\hline Research & 14,881 & 11,256 & 26,137 \\
Doctoral & $(57)$ & $(43)$ & 9,677 \\
& 6,399 & 3,278 & 639 \\
Comprehensive & $(66)$ & $(34)$ & 36,453 \\
& 447 & 192 & \\
\hline & $(70)$ & $(30)$ & \\
Total & 21,727 & 14,726 & $(40)$ \\
\end{tabular}

NOTE.-Numbers in parentheses are percentages.

likelihood that a faculty member works in a research university or another institutional type. To answer the research question, we ran two models. The first model predicts faculty status at research universities by examining doctoral preparation using Carnegie classifications, prior work experience, personal characteristics, and regional variables. The second model is similar to the first but substitutes the use of national rankings (U.S. Newes top 50) for Carnegie classification in the measure of doctoral preparation. These logistic regression models are summarized in table 5.

In both 1993 and 1999, individuals who received their doctorates from top 50 institutions were nearly 60 percent more likely than their peers from unranked institutions to work in a research university. In 1999 individuals who received their doctorate from doctoral universities were less than half as likely to work in research universities as those who received their doctorate from research universities, whereas in 1993 this difference was not statistically significant. Prior $\mathrm{K}-12$ teaching experience appeared not to influence the probability of working in a research university over working in a nonresearch university. That is, individuals with prior $\mathrm{K}-12$ teaching experience were equally likely to work in research or nonresearch university settings.

Personal attributes appear not to strongly influence sorting of teacher education faculty among research and nonresearch universities. We suspect, instead, that personal attributes play a stronger role at earlier stages of the pipeline, which influences access to academe more generally (i.e., variables such as age, gender, socioeconomic status, race, and marital status may affect which undergraduate and graduate schools individuals attend, which then may affect whether individuals pursue academic positions). Regional variables are strongly associated with probabilities that faculty work in research uni- 
TABLE 5

Factors Predicting Faculty Employment at Research Universities

\begin{tabular}{|c|c|c|c|c|}
\hline & \multicolumn{2}{|c|}{$\begin{array}{l}\text { NSOPF } 1993 \\
(\mathcal{N}=708)\end{array}$} & \multicolumn{2}{|c|}{$\begin{array}{l}\text { NSOPF } 1999 \\
(\mathcal{N}=486)\end{array}$} \\
\hline & $\begin{array}{l}\text { Carnegie } \\
\text { Model }\end{array}$ & $\begin{array}{l}\text { U.S. Nezws } \\
\text { Model }\end{array}$ & $\begin{array}{l}\text { Carnegie } \\
\text { Model }\end{array}$ & $\begin{array}{c}\text { U.S. Nezes } \\
\text { Model }\end{array}$ \\
\hline \multicolumn{5}{|l|}{ Preparation: } \\
\hline \multicolumn{5}{|l|}{ Doctoral institution: } \\
\hline Research university & $\ldots$ & . . & . . & . . \\
\hline Doctoral university & .67 & . . & $.42 * * *$ & $\cdots$ \\
\hline Other & .37 & $\ldots$ & .36 & $\ldots$ \\
\hline \multicolumn{5}{|l|}{ U.S. Newes ranking: } \\
\hline Unranked & . . & . . & . . & . . \\
\hline Top 50 & . & $1.57 * *$ & $\ldots$ & $1.59 * *$ \\
\hline \multicolumn{5}{|l|}{ Experience: } \\
\hline No $\mathrm{K}-12$ teaching & . & . . & $\ldots$ & $\ldots$ \\
\hline Previously taught $\mathrm{K}-12$ & .90 & .85 & .87 & .89 \\
\hline \multicolumn{5}{|l|}{ Personal: } \\
\hline \multicolumn{5}{|l|}{ Gender: } \\
\hline Female & $\cdots$ & . . & $\ldots$ & . . \\
\hline Male & 1.18 & 1.19 & 1.32 & 1.26 \\
\hline \multicolumn{5}{|l|}{ Race: } \\
\hline White & & & & . . \\
\hline Nonwhite & .96 & .91 & .93 & .97 \\
\hline \multicolumn{5}{|l|}{ Marital status: } \\
\hline Single/unmarried & & & . . & $\ldots$ \\
\hline Married & 1.03 & .99 & .79 & .83 \\
\hline Divorced/separated & .66 & .65 & .92 & .92 \\
\hline \multicolumn{5}{|l|}{ Region: } \\
\hline New England & 1.49 & 1.58 & 2.01 & 1.80 \\
\hline Middle Atlantic & $\ldots$ & . . & & $\ldots$ \\
\hline Great Lakes & $2.41 * *$ & $2.52^{* * *}$ & $3.06^{* * * *}$ & $3.06^{* * * *}$ \\
\hline Plains & 1.38 & 1.54 & $2.56^{* * *}$ & $2.58 * *$ \\
\hline Southeast & $1.92 *$ & $2.12^{* *}$ & $2.26 * *$ & $2.37 * *$ \\
\hline Southwest & $5.05 * * *$ & $5.50 * * *$ & $2.79 * *$ & $2.67 * *$ \\
\hline Rocky Mountain & $2.89 * * *$ & $3.27 * *$ & $8.21^{* * *}$ & $8.82^{* * * *}$ \\
\hline Far West & 1.25 & 1.28 & 1.32 & 1.34 \\
\hline Pseudo- $R^{2}$ & .046 & .046 & .066 & .054 \\
\hline
\end{tabular}

NOTE.-NSOPF $=$ National Survey of Postsecondary Faculty.

$* p<.10$.

$* * *<<.05$.

$* * * * 0.01$ 
versities. Faculty who live in the midwestern, western, and southwestern states are the most likely to work in research universities. As noted previously, the regional dummy variable was included primarily as a control variable, as we assumed the existence of regional labor markets and uneven regional distribution of research and nonresearch university opportunities. In sum, we conclude from this analysis that attending a top-ranked graduate school of education substantially influences whether someone becomes a faculty member in teacher education at a research university.

\section{Factors Predicting Which Doctoral Recipients in Teacher Education Pursue Faculty Jobs}

Table 6 presents three alternative models, using SED data, of the likelihood that a teacher education doctoral candidate pursues a faculty career in higher education. The first model examines the relationship between the Carnegie classification of one's doctorate and personal characteristics in order to predict the intention to pursue a faculty position. The second model uses top 50 ranking in place of Carnegie classification and also examines personal characteristics. The third model does not control for institutional type (this will occur in a subsequent analysis) but does include doctoral experience variables along with personal characteristics to predict faculty intentions.

The results suggest that graduates of doctoral institutions were only 70 percent as likely as graduates of research universities to pursue academic careers. Graduates of comprehensive institutions were 73 percent as likely and graduates of other institutions were only 35 percent as likely as graduates of research institutions to pursue academic careers. Graduates of top 50 graduate schools of education were 15 percent more likely to pursue academic careers than those graduates of unranked programs. Among predoctoral employment variables, individuals with fellowships or assistantships were nearly four times as likely as individuals who worked full time outside of academe to pursue faculty positions. Further, those who were already working full time in higher education were over six times as likely to pursue faculty careers. Individuals who were teaching in $\mathrm{K}-12$ schools while pursuing their doctorate were less than 50 percent as likely as other full-time employees to pursue academic careers. The only individuals less likely to pursue careers in academe were those who worked in nonteaching positions in $\mathrm{K}-12$ schools. We suspect that this pool includes a number of $\mathrm{K}-12$ administrators for whom the economic benefits of pursuing postsecondary careers are negative. ${ }^{9}$

Individuals who attended graduate school full time for no years or greater than six years were significantly less likely to pursue careers in academe than those who attended between one and three years. Individuals who incurred 
TABLE 6

Factors Predicting Which Doctoral Candidates in Teacher Education Pursue Faculty Careers

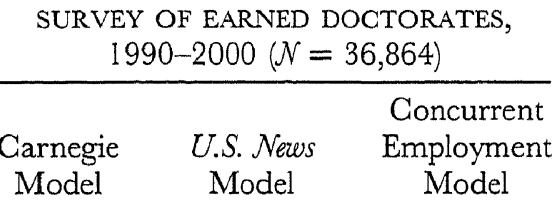

Preparation:

Carnegie classification:

Research I or II

Doctoral I or II

Comprehensive I or II

Other

$70^{* * * * *}$

$.73^{* * * *}$

$.35 * * * *$

U.S. Newes ranking:

Unranked

Top 50

Experience:

Pre-doctoral degree status:

Employed full time

Fellowship or assistantship

Part-time other

Not employed

Full-time college instructor

Teaching $\mathrm{K}-12$

$\mathrm{K}-12$ other

Full-time doctoral studies (years):

0

$1-3$

$4-6$

$>6$

Debt incurred (\$):

0

$<10,000$

$10,000-20,000$

20,000-30,000

$>30,000$

Other

Personal and family:

Dependents:

0

$1-2$

$>2$

Marital status:

Single/unmarried

Married

Divorced

Other relationship

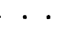

$\ldots$
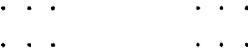

$3.70^{* * * *}$

.

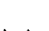

$2.00 * * *$

$1.36 * * * *$

$\ldots$

$6.25 * * *$

$.47 * * *$

$.16 * * *$

$\cdots$

$.78 * * *$

$\cdots$

98

$\ldots$

$.81 * * *$

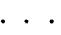

$1.35 * * * *$

$1.49 * * * *$

$1.52 * * * *$

$1.21 * * * *$

1.13 


\begin{tabular}{|c|c|c|c|}
\hline & \multicolumn{3}{|c|}{$\begin{array}{l}\text { SURVEY OF EARNED DOCTORATES, } \\
1990-2000(\mathcal{N}=36,864)\end{array}$} \\
\hline & $\begin{array}{l}\text { Carnegie } \\
\text { Model }\end{array}$ & $\begin{array}{l}\text { U.S. News } \\
\text { Model }\end{array}$ & $\begin{array}{c}\text { Concurrent } \\
\text { Employment } \\
\text { Model }\end{array}$ \\
\hline \multicolumn{4}{|l|}{ Gender: } \\
\hline Female & $\ldots$ & 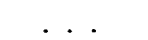 & $\ldots$ \\
\hline Male & .98 & .98 & $.93^{* *}$ \\
\hline \multicolumn{4}{|l|}{ Race: } \\
\hline White & $\ldots$ & $\ldots$ & $\ldots$ \\
\hline Nonwhite & $.62^{* * * *}$ & $.62 * * * *$ & $.55 * * *$ \\
\hline \multicolumn{4}{|l|}{ Age at degree: } \\
\hline$<30$ & $.77 * * * *$ & $.78 * * *$ & $.63 * * * *$ \\
\hline $30-40$ &.. & . . & . . \\
\hline$>40$ & $.74 * * * *$ & $.72^{* * * *}$ & $.89 * * * *$ \\
\hline \multicolumn{4}{|l|}{ Year of degree: } \\
\hline 1995-2000 & $\cdots$ & . & $\ldots$ \\
\hline $1990-95$ & $1.04^{*}$ & $1.05^{* *}$ & $1.10 * * *$ \\
\hline Pseudo- $R^{2}$ & .037 & .032 & .181 \\
\hline
\end{tabular}

more debt were more likely to pursue careers in academe. We suspect that these individuals are most likely to be those who attended relatively expensive graduate schools full time. While many may have had assistantships or fellowships, we suspect that these opportunities did not cover the full cost of their education. Among personal variables, as might be expected, greater numbers of dependents reduced the probability that an individual planned to pursue an academic career. Minorities pursued academic careers at lower rates, and individuals under 30 or over 40 were less likely than those between 30 and 40 when receiving their doctorate to pursue a faculty career in teacher education.

We concluded from these analyses that experiences in graduate school (i.e., holding a fellowship or an assistantship or working as a full-time college instructor prior to graduating) are very influential in determining whether an individual pursues a faculty career in education. In contrast, working full time in $\mathrm{K}-12$ is a significant negative predictor of pursuing a faculty career in education. We also note that full-time attendance in graduate school for one to six years positively influences the decision to become a teacher education faculty member, as does attending a top-ranked graduate school. While there are significant demographic variables in these models, they are in the direction 
that one would predict (i.e., being single, having no dependents, being female, being white, and being between the ages of 30 and 40 at the time of degree completion are positive predictors of pursuing a faculty career).

\section{Factors Associated with Engaging in "Favorable Work" Status in Graduate School}

Given that certain experiences in graduate school (holding an assistantship or working as a faculty member prior to graduation) were significant predictors of pursuing a faculty career once the doctorate was obtained, we sought to determine what factors, both institutional and demographic, predicted the likelihood of engaging in these experiences. We have labeled these two experiences as "favorable work" status. Table 7 parses out the predictors of holding a graduate assistantship or working full time as a faculty member before graduation. As noted in our Method section, we expect these opportunities to be more available in certain types of institutions and more accessible to individuals with certain personal attributes. Table 7 shows that individuals who did not attend research universities were substantially less likely to have a fellowship or assistantship. Individuals who attended top 50 graduate schools were 30 percent more likely than those who did not to have a fellowship or assistantship.

Institution effects are somewhat different for full-time employment status at postsecondary institutions during graduate school. We suspect that a significant share of individuals receiving doctorates at comprehensive institutions was already working full time in the same or similar institution where they eventually became a faculty member, hence the lack of differentiation between research and comprehensive institutions, and ranked and unranked institutions, as predictors of full-time college teaching prior to receiving the doctorate.

Recall that table 6 indicated that younger doctoral graduates were less likely to pursue academic careers and that fellowship or assistantship recipients were more likely to do so. However, table 7 indicates that younger doctoral candidates were much more likely to receive fellowships or assistantships than their older counterparts. This discrepancy offers evidence that there are two potential paths to the teacher education professoriate. Related evidence in table 7 shows that, while younger candidates were more likely to have fellowships and assistantships, older candidates (those over 40) were more likely to already be working full time as professors while in graduate school. Among other personal variables, number of dependents appears to reduce the probability that an individual had a fellowship or assistantship but increases the probability that an individual was already working full time in a college or university. Minorities were more likely to receive fellowships or assistantships in teacher education and less likely to be working full time in a college or 
Factors Associated with Engaging in "Favorable Work" Status in Graduate School

\begin{tabular}{|c|c|c|c|c|}
\hline & \multicolumn{2}{|c|}{$\begin{array}{l}\text { FELLOWSHIP OR } \\
\text { ASSISTANTSHIP }\end{array}$} & \multicolumn{2}{|c|}{$\begin{array}{c}\text { FULL-TIME COLLEGE } \\
\text { INSTRUCTOR/ } \\
\text { FACULTY }\end{array}$} \\
\hline & $\begin{array}{l}\text { Carnegie } \\
\text { Model }\end{array}$ & $\begin{array}{l}\text { U.S. News } \\
\text { Model }\end{array}$ & $\begin{array}{l}\text { Carnegie } \\
\text { Model }\end{array}$ & $\begin{array}{l}\text { U.S. Newes } \\
\text { Model }\end{array}$ \\
\hline \multicolumn{5}{|l|}{ Institution: } \\
\hline \multicolumn{5}{|l|}{ Carnegie classification: } \\
\hline Research I or II & . . & . . & . . & . . \\
\hline Doctoral I or II & $.52 * * * *$ & . . & $.90^{* * * *}$ & . . \\
\hline Comprehensive I or II & $.38 * * *$ & . . & 1.04 & . . \\
\hline Other & $.14 * * *$ &.. & $.77^{*}$ &.. \\
\hline \multicolumn{5}{|l|}{ U.S. Newes ranking: } \\
\hline Unranked & $\ldots$ & . . & . . & . . \\
\hline Top 50 & . . & $1.31 * * *$ & . . & 1.02 \\
\hline \multicolumn{5}{|l|}{ Personal: } \\
\hline \multicolumn{5}{|l|}{ Age at degree: } \\
\hline$<30$ & $\cdots$ & . . . & . . & . . \\
\hline $30-40$ & $.77 * * *$ & $.78 * * * *$ & $1.22 * * *$ & $1.22^{* * * *}$ \\
\hline$>40$ & $.60 * * *$ & $.60 * * *$ & $1.18^{* * * *}$ & $1.18 * * *$ \\
\hline \multicolumn{5}{|l|}{ Marital status: } \\
\hline Single/unmarried & $\cdots$ & $\cdots$ & . . & . . . \\
\hline Married & $.79 * * * *$ & $.79 * * * *$ & .99 & .99 \\
\hline Divorced & .94 & .94 & .99 & .99 \\
\hline Other relationship & $.47 * * *$ & $.46^{* * * *}$ & $.33 * * *$ & $.33^{* * * *}$ \\
\hline \multicolumn{5}{|l|}{ Dependents: } \\
\hline 0 & $\cdot$ & . . & . . . & . . \\
\hline $1-2$ & $1.14 * * *$ & $1.14 * * * *$ & $1.09 * * *$ & $1.09 * * *$ \\
\hline$>2$ & $\ldots$ & . . & . . & . . \\
\hline \multicolumn{5}{|l|}{ Gender: } \\
\hline Female & $1.10^{* *}$ & $1.09 * * *$ & $.93^{* * *}$ & $.93^{* * *}$ \\
\hline Male & $\cdots$ & . . & . . & . . \\
\hline Race: & $2.24 * * *$ & $2.24 * * * *$ & $.42 * * *$ & $.42 * * * * *$ \\
\hline White & $\ldots$ & . . & $\ldots$ & . . \\
\hline Nonwhite & $.39 * * *$ & $.38 * * *$ & $1.25^{* * *}$ & $1.24 * * *$ \\
\hline \multicolumn{5}{|l|}{ Year of degree: } \\
\hline $1995-2000$ & . & . . & . . & $\cdots$ \\
\hline 1990-95 & $.71^{* * *}$ & $.72 * * *$ & $1.21 * * *$ & $1.21 * * *$ \\
\hline Pseudo- $R^{2}$ & .086 & .076 & .019 & .018 \\
\hline
\end{tabular}

$* p<.10$.

$* * p<.05$.

$* * * \quad p<.01$. 
university prior to graduation. These potentially different pathways to the professoriate are explored in the following section.

\section{Factors Associated with Attending the "Right" Graduate School}

We had a suspicion that if we looked back at the academic backgrounds of teacher education doctoral recipients we might learn more about their career choices. As such, table 8 goes one step further backward into the lives of faculty and other doctoral recipients in teacher education by examining the selectivity of their undergraduate school and personal variables as factors that predict the type of graduate school teacher education doctoral recipients attended. Table 8 indicates that undergraduate selectivity is a strong predictor of the likelihood of earning a doctorate in teacher education from a research university or a top 50 graduate school of education. Being under 30 is also a significant predictor of attending a research university, as is being single with no dependents and being a person of color.

\section{Discussion}

The results of our study illuminate some of the characteristics and experiences that help predict who becomes a teacher education faculty member and how these faculty members are dispersed across institutional types. The descriptive data suggest that a sizable proportion of the potential pool of faculty members in teacher education is being diverted to other work settings, especially within the $\mathrm{K}-12$ arena. Specifically, the number of doctorate holders in teacher education fields seeking nonfaculty positions is substantially greater than the number seeking academic positions in higher education. External factors contributing to this trend were discussed earlier in the article.

Our analysis helps to identify more clearly the experiences of (1) individuals who pursue faculty positions and (2) those most likely to pursue faculty jobs in research universities. Individuals who earn doctoral degrees at research universities are most likely to pursue faculty careers, although graduates of doctoral and comprehensive universities are only somewhat less likely to do so. Attending a top 50 university provides an edge over attending an unranked institution. Holding fellowships/assistantships, attending full time for longer, incurring more debt-attending graduate school full time-were positively related to pursuing faculty positions. However, individuals who were already working in higher education while pursuing the doctoral degree were much more likely to pursue faculty jobs. Negatively related to faculty aspirations are working full time in $\mathrm{K}-12$ schools, attending graduate school part time, having 
TABLE 8

Factors Associated with Attending the "Right" Graduate School

\begin{tabular}{|c|c|c|}
\hline & Carnegie Model & U.S. Newes Model \\
\hline \multicolumn{3}{|l|}{ Undergraduate selectivity: } \\
\hline Nonselective & $.72^{* * * *}$ & $.45^{* * * *}$ \\
\hline Less selective & $.76^{* * * *}$ & $.80^{* * * * *}$ \\
\hline Selective & $\ldots$ & \\
\hline Very selective & $1.21 * * * *$ & $1.26^{* * * * *}$ \\
\hline Highly selective & $1.47^{* * * *}$ & $1.63^{* * * *}$ \\
\hline Most selective & $1.33^{* * * *}$ & $2.37 * * *$ \\
\hline \multicolumn{3}{|l|}{ Personal: } \\
\hline \multicolumn{3}{|l|}{ Age at degree: } \\
\hline$<30$ & $1.16^{*}$ & 1.05 \\
\hline $30-40$ & . . & . . \\
\hline$>40$ & $.64 * * * *$ & $.70 * * * *$ \\
\hline \multicolumn{3}{|l|}{ Marital status: } \\
\hline Single/unmarried & $\ldots$ & . . \\
\hline Married & $.89 * * * *$ & $.82 * * *$ \\
\hline Divorced & $.86^{* * * *}$ & $.79 * * * *$ \\
\hline Other relationship & $.70^{* * * *}$ & $.69 * * * *$ \\
\hline \multicolumn{3}{|l|}{ Dependents: } \\
\hline 0 & $\cdots$ & $\ldots$ \\
\hline $1-2$ & .99 & $.92^{* * * *}$ \\
\hline$>2$ & $.94 *$ & $.85^{* * * *}$ \\
\hline \multicolumn{3}{|l|}{ Gender: } \\
\hline Female & $\ldots$ & $\ldots$ \\
\hline Male & 1.02 & 1.00 \\
\hline \multicolumn{3}{|l|}{ Race: } \\
\hline White & . . & - \\
\hline Nonwhite & $1.10^{* * * *}$ & $1.27 * * * *$ \\
\hline \multicolumn{3}{|l|}{ Year of degree: } \\
\hline $1995-2000$ & . & $\therefore$ \\
\hline $1990-95$ & $1.13^{* * * *}$ & $1.16^{* * * *}$ \\
\hline Pseudo- $R^{2}$ & .018 & .028 \\
\hline
\end{tabular}

$* p<.10$.

$* * * * p<.01$.

more children, being a minority, and being younger when receiving the doctorate.

Going back even further we identified factors that predicted two of the most prominent paths to the faculty: going to graduate school full time and holding assistantships or full-time employment in higher education. Attending a top 50 graduate school of education is key to holding a faculty position at a research university. This finding is linked to the significantly increased likelihood of holding an assistantship or fellowship among those who attended 
top 50 graduate schools of education. Attending a selective undergraduate institution is a strong predictor of attending a top 50 graduate school of education, as is being under 30 , being single, having no dependents, and being a person of color. A different path emerges for individuals who were employed full time in higher education while earning their doctorate. These individuals were likely to earn their doctorate at comprehensive or doctoral institutions, perhaps because they were working in the same or a nearby institution. These individuals were older and had more dependents.

In line with theories about the academic labor market, the pipeline to faculty positions in teacher education in research universities indicates preferences for the academic elite (Burke 1988; Lewis 1975; Youn 1988). That is, individuals who attended highly selective undergraduate institutions were more likely to receive their doctorates from top-ranked research universities, to have fellowships or assistantships in graduate school, to attend graduate school full time, and to pursue academic careers at research universities. The individuals who followed this path were also more likely to be younger than 30 , single with no dependents, male, and persons of color. As predicted by the academic labor market literature, this was the "sure" path to the professoriate.

The elite pathway to the professoriate in education raises some interesting concerns in light of disciplinary preferences to hire individuals with public $\mathrm{K}-12$ teaching experience into faculty positions (Twombly et al. 2003). Specifically, only 7 percent of all public school teachers attended highly or most selective colleges - a major factor in the elite pathway. ${ }^{10}$ Those who did were more likely to have been certified through alternative or nontraditional routes or not at all, to have worked for shorter periods in public schooling, and to have worked in nontraditional or charter schools than in conventional public schools (Baker and Dickerson 2004; Henke et al. 2000; Reback 2002). Teacher education faculty who fit this elite profile may be out of touch with the needs of public $\mathrm{K}-12$ institutions and may not be adequately prepared to train teachers for the public schools.

In contrast to academic labor market theory, however, the elite path was one not taken by many who pursued academic careers in teacher education. Recall from the descriptive statistics that only 15 percent of those who earned doctorates in education attended highly or most-selective undergraduate institutions, only 17 percent held fellowships or assistantships, only 17 percent were single, and only 3 percent were under the age of 30 when they earned their doctorates. Thus, while this path to the professoriate is a direct route and one that is in line with the research on the academic labor market, very few individuals took this path.

The dominant pathway to the teacher education professoriate appears to be at odds with the research on traditional academic labor markets that stresses a hierarchical sorting of academic positions (Youn 1988). Our data suggest 
that this "alternative" path is, in fact, the road most traveled-as perhaps 85 percent of the teacher education faculty do not follow the elite path outlined above. The dominant path consists of individuals who are older and who worked full time in graduate school within the public schools or as full-time faculty members before graduating with their doctorates. The presence of this path suggests that schools of education are more "democratic" and less hierarchical in their hiring practices than are other fields or than would be predicted by academic labor market theory. Faculty who take this other path might be better prepared to train preservice teachers to work in the public schools, as they have ample experience in this milieu. The potential downside to this pathway is that these faculty members may not be socialized or prepared to meet the scholarly expectations of a research university, which could have a negative effect on the faculty member's ability to earn tenure, to train future doctoral students, and to conduct needed cutting-edge research on the public schools. It could also have a negative effect on the status and respect accorded to schools of education by others both in the public and university realm. Researchers have already noted the lack of intellectualism of many teacher education faculty members, which could be the result of the pathway taken to assume a faculty position in the field (Ducharme and Agne 1982; Labaree 2003).

More research into this large group of faculty members is necessary in order to parse out the path that they have taken to the professoriate, as their path to the faculty is not as clearly demarcated as it is for their counterparts who followed the more conventional, elite path. How long did this group teach in $\mathrm{K}-12$ settings? What kinds of institutions are they currently employed in? Did they stay at the same institution where they were working prior to graduation once they had earned their doctorates? Were they more likely to work at research universities or other institutional types? These and other questions are worthy of further exploration, as this group numerically seems to represent a large proportion of today's teacher education faculty.

In many respects, the present study raises more questions than it answers. Because there is such overlap among the independent variables, it is necessary to present the data step by step. The problem with this approach, however, is that it becomes impossible to look at the effect of the various steps simultaneously. Nonetheless, these data offer a helpful glimpse into understanding the academic labor market for teacher education faculty. The data suggest that this is a leaky pipeline, with 60 percent of those who earn doctorates in teacher education opting to pursue careers outside of academe. Of those who pursue faculty careers, it appears as though there is more than one pathway to the professoriate. A path taken by very few, the academic elite, mirrors the path found in other academic disciplines. At the same time there exist other pathways to the professoriate that appear to look quite different than what 
the traditional academic labor market would predict. These various pathways, along with the leaks, deserve our attention from both a research and policy perspective.

From a practical perspective there are things that teacher education programs in research universities can do to stop the leaks at the highest levels. Namely, they can and must look at ways to encourage promising teachers to consider entering the professoriate, and they must make it attractive for them to get the kind of training necessary.

Further, our research shows that graduate students who had fellowships or assistantships were more likely to become faculty and that younger doctoral candidates (those receiving doctorates by the age of 30) were more likely to hold such fellowships and assistantships. By extension, an individual who receives his/her doctorate by age 30 is likely to have no more than a few years of full-time K-12 teaching experience. One may ask, though, whether research universities, which value certain sets of skills, can find qualified teacher educators who have ample public school teaching experience.

Researchers in the field have hypothesized several explanations for this. First, salaries in higher education are not competitive with the types of positions in the $\mathrm{K}-12$ sector for which doctorates are required. Second, individuals who earn doctorates in teacher education are not as mobile as the academic labor market would expect them to be (due to factors such as age, gender, and marital status). And, third, individuals who earn doctorates in education are neither as interested in research nor as intrigued by the academic lifestyle as are doctoral recipients in other fields (Castle and Arends 2003; Ducharme and Agne 1989; Labaree 2003; Twombly et al. 2003). 
Appendix

TABLE Al

Summary Statistics for NSOPF Data

\begin{tabular}{|c|c|c|c|c|}
\hline & \multicolumn{2}{|c|}{ NSOPF 1993} & \multicolumn{2}{|c|}{ NSOPF 1999} \\
\hline & No & Yes & No & Yes \\
\hline Teaches at research university & $\begin{array}{l}519 \\
(75.00)\end{array}$ & $\begin{array}{l}173 \\
(25.00)\end{array}$ & $\begin{array}{l}306 \\
(64.29)\end{array}$ & $\begin{array}{l}170 \\
(35.71)\end{array}$ \\
\hline \multicolumn{5}{|l|}{ Doctorate-granting institution: } \\
\hline \multicolumn{5}{|l|}{ Carnegie classification: } \\
\hline Research & . . & $\begin{array}{l}546 \\
(76.15)\end{array}$ & $\cdots$ & $\begin{array}{l}391 \\
(77.89)\end{array}$ \\
\hline Doctoral & $\cdots$ & $\begin{array}{l}136 \\
(18.97)\end{array}$ & $\cdot \cdot$ & $\begin{array}{l}79 \\
(15.74)\end{array}$ \\
\hline Comprehensive & $\cdots$ & $\begin{array}{l}10 \\
(1.39)\end{array}$ & $\cdot \cdot$ & $\begin{array}{l}6 \\
(1.20)\end{array}$ \\
\hline Other & $\cdots$ & $\begin{array}{l}25 \\
(3.49)\end{array}$ & $\cdots$ & $\begin{array}{l}26 \\
(5.18)\end{array}$ \\
\hline U.S. News top 50 ranking & $\begin{array}{l}356 \\
(49.65)\end{array}$ & $\begin{array}{l}361 \\
(50.35)\end{array}$ & $\begin{array}{l}257 \\
(51.20\end{array}$ & $\begin{array}{l}245 \\
(48.80)\end{array}$ \\
\hline \multicolumn{5}{|l|}{ Personal information: } \\
\hline Male & $\begin{array}{l}398 \\
(55.51)\end{array}$ & $\begin{array}{l}319 \\
(44.49)\end{array}$ & $\begin{array}{l}297 \\
(59.16)\end{array}$ & $\begin{array}{l}205 \\
(40.84)\end{array}$ \\
\hline Nonwhite & $\begin{array}{l}564 \\
(78.66)\end{array}$ & $\begin{array}{l}153 \\
(21.34)\end{array}$ & $\begin{array}{l}395 \\
(78.69)\end{array}$ & $\begin{array}{l}107 \\
(21.31)\end{array}$ \\
\hline \multicolumn{5}{|l|}{ Marital status: } \\
\hline Unmarried & $\cdots$ & $\begin{array}{l}126 \\
(17.57)\end{array}$ & $\cdots$ & $\begin{array}{l}53 \\
(10.55)\end{array}$ \\
\hline Married & . . & $\begin{array}{l}495 \\
(69.04)\end{array}$ & $\cdots$ & $\begin{array}{l}353 \\
(70.32)\end{array}$ \\
\hline Divorced & $\cdots$ & $\begin{array}{l}87 \\
(12.13)\end{array}$ & $\cdots$ & $\begin{array}{l}80 \\
(15.94)\end{array}$ \\
\hline Other & $\cdots$ & $\begin{array}{l}9 \\
(1.26)\end{array}$ & $\cdots$ & $\begin{array}{l}16 \\
(3.19)\end{array}$ \\
\hline \multicolumn{5}{|l|}{ Geographic region: } \\
\hline New England & $\cdots$ & $\begin{array}{l}38 \\
(5.33)\end{array}$ & $\cdots$ & $\begin{array}{l}27 \\
(5.38)\end{array}$ \\
\hline Middle Atlantic & . & $\begin{array}{l}98 \\
(13.67)\end{array}$ & . . & $\begin{array}{l}83 \\
(16.53)\end{array}$ \\
\hline Great Lakes & $\cdot \cdot$ & $\begin{array}{l}145 \\
(20.22)\end{array}$ & $\cdot \cdot$ & $\begin{array}{l}87 \\
(17.33)\end{array}$ \\
\hline Plains & $\cdots$ & $\begin{array}{l}98 \\
(13.67)\end{array}$ & $\cdots$ & $\begin{array}{l}52 \\
(10.36)\end{array}$ \\
\hline Southeast & . . & $\begin{array}{l}197 \\
(27.48)\end{array}$ & $\cdots$ & $\begin{array}{l}144 \\
(28.69)\end{array}$ \\
\hline
\end{tabular}




\begin{tabular}{lccccc}
\hline & \multicolumn{2}{c}{ NSOPF } & 1993 & & \multicolumn{2}{c}{ NSOPF } & 1999 \\
\cline { 5 - 6 } & No & Yes & & No & Yes \\
\hline Southwest & $\ldots$ & 58 & & $\ldots$ & 35 \\
Rocky Mountain & $\ldots$ & 28 & & $\ldots$ & $(6.97)$ \\
& & & $(3.91)$ & & 27 \\
Far West & $\ldots$ & 55 & & $\ldots$ & 47 \\
& & $(7.67)$ & & $(9.38)$ \\
& & & & & \\
\hline
\end{tabular}

NOTE.-NSOPF = National Survey of Postsecondary Faculty. Number is unweighted. Numbers in parentheses indicate percentages.

TABLE A2

Summary Statistics for SED Data

\begin{tabular}{|c|c|c|c|c|}
\hline & \multicolumn{2}{|c|}{ NO } & \multicolumn{2}{|c|}{ YES } \\
\hline & Number & Percent & Number & Percent \\
\hline \multicolumn{5}{|l|}{ Pursuing career as post- } \\
\hline secondary faculty & 22,060 & 59.83 & 14,810 & 40.17 \\
\hline \multicolumn{5}{|l|}{ Graduate preparation: } \\
\hline \multicolumn{5}{|l|}{ Carnegie classification: } \\
\hline Research & . & . & 26,131 & 70.88 \\
\hline Doctoral & $\ldots$ & ... & 9,677 & 26.25 \\
\hline Comprehensive & . & & 639 & 1.73 \\
\hline Other & . . & . & 417 & 1.13 \\
\hline U.S. News top 50 ranking & 19,837 & 53.81 & 17,027 & 46.19 \\
\hline \multicolumn{5}{|l|}{ Undergraduate preparation: } \\
\hline \multicolumn{5}{|l|}{ Barron's Profiles rating: } \\
\hline Nonselective & . & . & 975 & 2.64 \\
\hline Less selective & . . & & 3,263 & 9.83 \\
\hline Selective & . . . & $\ldots$ & 12,371 & 33.56 \\
\hline Very selective & . & & 6,722 & 18.23 \\
\hline Highly selective & $\ldots$ & & 3,256 & 8.83 \\
\hline Most selective & $\ldots$ & & 2,124 & 5.76 \\
\hline Special/other* & . & & 7,793 & 21.14 \\
\hline \multicolumn{5}{|l|}{ Experience: } \\
\hline \multicolumn{5}{|l|}{ Pre-doctoral degree status: } \\
\hline Employed full time & . & . & 6,769 & 18.36 \\
\hline Fellowship or assistantship & & & 6,212 & 16.85 \\
\hline Part-time other & .. & $\cdots$ & 4,751 & 12.89 \\
\hline Not employed & $\ldots$ & & 2,530 & 6.86 \\
\hline Full-time college instructor & $\cdots$ & $\ldots$ & 7,583 & 20.57 \\
\hline
\end{tabular}




\begin{tabular}{|c|c|c|c|c|}
\hline & \multicolumn{2}{|c|}{ NO } & \multicolumn{2}{|c|}{ YES } \\
\hline & Number & Percent & Number & Percent \\
\hline Teaching $\mathrm{K}-12$ & . . & . . & 3,991 & 10.83 \\
\hline $\mathrm{K}-12$ other & . . & . . & 2,912 & 7.90 \\
\hline \multicolumn{5}{|c|}{ Full-time doctoral studies (years): } \\
\hline 0 & . . & . . & 2,673 & 7.25 \\
\hline $1-3$ & . . & . . & 8,468 & 22.97 \\
\hline $4-6$ & $\ldots$ & $\ldots$ & 12,169 & 33.01 \\
\hline$>6$ & $\ldots$ & . . & 13,554 & 36.77 \\
\hline \multicolumn{5}{|l|}{ Debt incurred (\$): } \\
\hline 0 & . . & . . & 21,310 & 57.81 \\
\hline$<10,000$ & $\ldots$ & $\ldots$ & 6,875 & 18.65 \\
\hline $10,000-20,000$ & . . & . . & 3,293 & 8.93 \\
\hline $20,000-30,000$ & $\ldots$ & $\cdots$ & 1,954 & 5.30 \\
\hline$>30,000$ & . . & . . & 2,522 & 6.84 \\
\hline Other & . . & . . & 910 & 2.47 \\
\hline \multicolumn{5}{|l|}{ Personal and family: } \\
\hline \multicolumn{5}{|l|}{ Dependents: } \\
\hline 0 & . . & . . & 14,586 & 39.57 \\
\hline $1-2$ & $\ldots$ & $\ldots$ & 12,957 & 35.15 \\
\hline$>2$ & . . & $\ldots$ & 9,321 & 25.28 \\
\hline \multicolumn{5}{|l|}{ Marital status: } \\
\hline Single/unmarried & . . & . . & 6,182 & 16.77 \\
\hline Married & $\cdots$ & . . & 22,838 & 61.95 \\
\hline Divorced & $\ldots$ & . . & 4,764 & 12.92 \\
\hline Other relationship & . . & $\ldots$ & 3,083 & 8.36 \\
\hline \multicolumn{5}{|l|}{ Gender: } \\
\hline Male & 24,124 & 65.44 & 12,740 & 34.56 \\
\hline \multicolumn{5}{|l|}{ Race: } \\
\hline Nonwhite & 27,831 & 75.50 & 9,033 & 24.50 \\
\hline \multicolumn{5}{|l|}{ Age at degree: } \\
\hline$<30$ & $\ldots$ & $\ldots$ & 1,094 & 2.97 \\
\hline $30-40$ & $\cdots$ & $\ldots$ & 13,900 & 37.71 \\
\hline$>40$ & $\ldots$ & $\ldots$ & 21,870 & 59.33 \\
\hline \multicolumn{5}{|l|}{ Year of degree: } \\
\hline $1995-2000$ & $\ldots$ & $\ldots$ & 16,747 & 45.43 \\
\hline 1990-95 & $\cdots$ & $\ldots$ & 20,117 & 54.57 \\
\hline
\end{tabular}

NOTE.-SED = Survey of Earned Doctorates.

* Barron's Profiles "special" is excluded from the analysis. 


\section{Notes}

We dedicate this article to Nona Tollefson, a loyal and trusted colleague who provided inspiration, guidance, and a touch of humor. She passed away while the article was under review. We miss her greatly.

1. We include faculty who identified their field of study in one of the following categories: education, bilingual education, curriculum and instruction, educational psychology, special education, other education, preelementary, elementary, secondary, other teacher education, and teacher education specialized subjects.

2. We include all individuals who earned doctorates in the following fields: general curriculum and instruction; early childhood; elementary, middle, or secondary education; special education; math education; science education; social studies education; art education; reading education; English education; music education; English as a Second Language education; foundations of education; and education technology.

3. See http://www.usnews.com/usnews/edu/grad/rankings/about/05method_brief .php for a brief synopsis of the underlying methodology for the U.S. Neres rankings. The 1994 Carnegie system classifies institutions of higher education according to number and type of degrees awarded and externally funded research. Research I institutions, for example, offer a full range of baccalaureate programs, award 50 or more doctoral degrees each year, and receive $\$ 40$ million or more in federal support annually. Research II universities are like Research I institutions but receive $\$ 15.5-\$ 40$ million in federal support annually. Doctoral I institutions offer a full range of baccalaureate programs and award at least 40 doctoral degrees annually in five or more disciplines. Doctoral II award at least 10 doctoral degrees in three or more disciplines or 20 or more doctoral degrees in one or more disciplines. Comprehensive I institutions offer a full range of baccalaureate programs and award 40 or more master's degrees annually in three or more disciplines. Comprehensive II institutions award 20 or more master's degrees annually in one or more disciplines. The U.S. Neves top 50 constitute a large share of but not all Research I institutions. There were, during the period studied, 88 Research I institutions and a total of 125 Research I and II institutions.

4. Again, research universities constitute a larger group than the top 50, with 125 Research I and II institutions.

5. In the case of our SED data, teaching (GTA) or research (GRA) assistantships are operationalized into the single variable indicating that the individual held a fellowship or assistantship.

6. In other versions in progress, we test a variety of selection models (Heckman's probit) to account for bias in who is able (by personal attributes) to attend research universities or highly ranked universities for their doctoral studies, and we also conducted simultaneous equations (seemingly unrelated logistic regressions) for doctoral employment status and doctoral institution type. This juncture of the pipeline in particular deserves much greater attention in future analyses, both in terms of descriptive analysis and alternative predictive models.

7. Factors included in determining the category for each college included median entrance exam scores for the 2001-2 freshman class (the SAT I score used was derived by averaging the median verbal reasoning and the median mathematics reasoning scores; the ACT score used was the median composite score); percentage of 2001-2 freshmen scoring 500 and above and 600 and above on both the verbal reasoning and mathematics reasoning sections of the SAT I; percentage of 2001-2 freshmen scoring 21 and above and 27 and above on the ACT; percentage of 2001-2 freshmen who ranked in the upper fifth and upper two-fifths of their high school graduating class; 
minimum class rank and grade point average required for admission (if any); and percentage of applicants to the 2001-2 freshman class who were accepted. Our Barron's Profiles ratings are more recent than the time period over which 1999 Schools and Staffing Survey (SASS 99) teachers attended colleges. We assume relative stability over time to the highest categories of selectivity.

8. In STATA 8.0, sampling probability weights are specified with the pweight command, indicating, for example, that a particular survey participant represents perhaps 3,5 , or 20 faculty members in the total population with comparable attributes (perhaps race, ethnicity, gender, etc.) to him/her. If, however, we estimate statistical significance as if the sampled individual actually counted as 20 individuals who answered the survey exactly the same on all responses, we might overstate differences among faculty by artificially inflating sample size. For example, one sampled faculty member might represent 20 in the population and should be weighted accordingly. But, that survey respondent should not be treated as if he or she were 20 actual respondents providing precisely the same answer. The primary sampling unit, for purposes of standard error calculation, remains the sampled faculty member $(n=1)$, not the population the faculty member represents. Robust standard error estimation adjusts sample size to the actual primary sampling unit or surveyed faculty member.

9. We suspect that this pool includes school-level administrators and district-level "middle" administrators such as curriculum coordinators who may be more marketable within their profession if they hold a doctoral degree. For these positions, doctoral degrees specific to educational administration may not be required and, in fact, may be less relevant than doctoral degrees in curriculum and instruction, assuming a master's in educational administration is already held. Related research by the authors using the SED explores academic paths to $\mathrm{K}-12$ leadership and the educational administration professoriate.

10. For example, nearly 40 percent of teachers in SASS 99 attended comprehensive colleges in the lowest three categories of selectivity, and only 7 percent attended a college or university in the top two categories of selectivity. Further, only a small share of that 7 percent are currently pursuing doctoral studies.

\section{References}

Baker, Bruce, and Jill Dickerson. 2004. "Charter Schools, Teacher Labor Market Deregulation and Teacher Quality: Evidence from the Schools and Staffing Survey." Paper presented at the annual meeting of the American Educational Research Association, San Diego, April, http://www.ku.edu/ bdbaker/papers/aera04a.pdf.

Burke, Delores. 1988. A New Academic Marketplace. Westport, CT: Greenwood.

Caplow, Theodore, and Reece McGee. 1958. The Academic Labor Marketplace. New York: Basic.

Castle, Sharon, and Richard Arends. 2003. "Faculty Supply and Demand in Education." Fournal of Teacher Education 54 (2): 112-21.

Ducharme, Edward, and Russell Agne. 1982. "The Education Professoriate: A Research-Based Perspective." Fournal of Teacher Education 33 (6): 30-36.

Ducharme, Edward, and Russell Agne. 1989. "Professors of Education: Uneasy Residents of Academe." In The Professors of Teaching: An Inquiry, ed. Richard Wisniewski and Edward Ducharme. Albany: State University of New York Press.

Eide, Eric, Dominic Brewer, and Richard Ehrenberg. 1998. "Does It Pay to Attend 
an Elite Private College? Evidence on the Effects of Undergraduate College Quality on Graduate School Attendance." Economics of Education Reviere 17 (4): 371-76.

Farrell, Elizabeth. 2001. "Number of Ph.D.'s Awarded Rebounds after 1-Year Dip." Chronicle of Higher Education 48 (14): A10-A11.

Finnegan, Dorothy. 1993. "Segmentation in the Academic Labor Market: Hiring Cohorts in Comprehensive Universities." Fournal of Higher Education 64 (6): 621-56.

Henke, Robin, Xiangle Chen, and Sonja Geis. 2000. "Progress through the Teacher Education Pipeline: 1992-93 College Graduates and Elementary/Secondary School Teaching as of 1997." Report. Office of Educational Research and Improvement, U.S. Department of Education, Washington, DC (NCES 2000-152).

Labaree, David. 2003. The Trouble with Ed Schools. New Haven, CT: Yale University Press.

Lewis, Lionel. 1975. Scaling the Ivory Tower: Merit and Its Limits in Academic Careers. Baltimore: Johns Hopkins Press.

National Center for Education Statistics. 2002. "Full-Time and Part-Time Instructional Faculty and Staff at Institutions of Higher Education, by Type and Control, Academic Rank, Age, Salary, Race/Ethnicity, and Sex." Digest of Education Statistics, 2001. Washington DC: U.S. Department of Education.

Perna, Laura. 2001. "The Relationship between Family Responsibilities and Employment Status." Fournal of Higher Education 72 (5): 584-611.

Reback, Randall. 2002. "The Impact of College Course Offerings on the Supply of Academically Talented Public School Teachers." Working paper, National Bureau of Economic Research, Cambridge, MA.

Reys, Robert. 2002. "Mathematics Education Positions in Higher Education and Their Applicants: A Many-to-One Correspondence." Notices of the AMS 49 (2): 202-7.

Smith, Deborah, G. Pion, N. C. Tyler, P. Sindelar, and M. Rosenberg. 2001. "The Study of Special Education Leadership Personnel with Particular Attention to the Professorate." Report submitted to the U.S. Department of Education, Washington, DC.

Tierney, William. 2001. "Faculty of Education in a Period of Systemic Reform." In Faculty Work in Schools of Education: Rethinking Roles and Rewwards for the Twenty-First Century, ed. William Tierney. Albany: State University of New York Press.

Turner, Sarah. 2001. "The Evolving Production Functions of Schools of Education." In Faculty Work in Schools of Education: Rethinking Roles and Rewards for the Twenty-First Century, ed. William Tierney. Albany: State University of New York Press.

Twombly, Susan, Lisa Wolf-Wendel, and James Williams. 2003. "Searching for the Next Generation of Teacher Educators: Assessing the Success of Academic Searches." Paper presented at the annual meeting of the American Educational Research Association, Chicago, April.

Wolf-Wendel, Lisa. 1998. "Models of Excellence: The Baccalaureate Origins of Successful European American Women, African American Women and Latinas." Fournal of Higher Education 69 (2): 144-72.

Wolf-Wendel, Lisa, Susan Twombly, and Suzanne Rice. 2003 The Two-Body Problem: Dual Career Couples Hiring Policies in Higher Education. Baltimore: Johns Hopkins Press.

Youn, Ted. 1988. "Studies of Academic Markets and Careers: An Historic Review." In Academic Labor Markets and Careers, ed. David Breneman and Ted Youn. New York: Falmer.

Zimpher, Nancy, and James Sherrill. 1996. "Professors, Teachers, and Leaders in SCDES." In Handbook of Research on Teacher Education, ed. John Sikula. 2nd ed. New York: Association of Teacher Educators. 